\title{
Adaptive Significance of Within-site Variation in Morphological and Reproductive Traits of Naturalized Wild Radish (Raphanus raphanistrum) Populations in South-Western Australia
}

\author{
Muhammad Ali Bhatti ${ }^{1,2,3 *}$, Phillip Stanley Cocks ${ }^{1,4}$, Sarita Jane Bennett ${ }^{1,5}$ and Aman Ullah Malik ${ }^{1,6}$ \\ ${ }^{1}$ School of Plant Biology, The University of Western Australia, 35 Stirling Highway, Crawley, Western Australia, 6009, \\ Australia \\ ${ }^{2}$ IP Australia, PO Box 200 Woden ACT 2606, Australia \\ ${ }^{3}$ Department of Business Administration (Agribusiness), Sukkur Institute of Business Administration, (Sukkur IBA) Air Port \\ Road, Sukkur, Sindh, Pakistan \\ ${ }^{4} 143$ Minsterly Road, Denmark, WA, 6333, Australia \\ ${ }^{5}$ Curtin University of Technology, GPO Box U1987, Perth, WA 6845, Australia \\ ${ }^{6}$ Institute of Horticultural Sciences, University of Agriculture Faisalabad, Pakistan \\ *For correspondence: Ali.Bhatti@ipaustralia.gov.au; mbhattipbr@gmail.com
}

\begin{abstract}
Genotypic variation between and within populations of the outbreeding wild radish (Raphanus raphanistrum L.), was studied using seeds collected from 55 sites across the West Australian wheat belt along 2 transects in December 1999 and February 2000. The seeds were grown at the University of Western Australia field station at Shenton Park, Perth, WA over the 2000 growing season, and 14 morphological and phenological characters were scored. A high degree of variation was present in all traits, and within site variation was greater than between sites. The greatest variation was recorded in the reproductive traits such as time to flowering, seed weight, and pod weight. Variation between sites was associated with geo-clusters based primarily on rainfall and temperature. Populations from sites with a high annual rainfall and low average temperature had longer and wider pods, larger seeds and pods with more segments, compared to populations from sites with a low annual rainfall and a high average temperature. These plants also tended to flower later than those from hotter, drier sites. The results show that wild radish in the wheat-belt of Western Australia has formed genotypically distinct populations in the 150 years since it was introduced, that are adapted to the climate at the site of collection. (C) 2016 Friends Science Publishers
\end{abstract}

Keywords: Wild radish; Raphanus raphanistrum; Genotypic variation; Morphology; Life history traits; Adaptation

\section{Introduction}

Genotypic variation in populations is the expression of morphological and phenotypic differences between and within populations for the traits concerned and is typically measured in a common environment. There are a number of factors responsible for creating genetic variation, such as mutation, recombination, genetic drift, mating system, gene flow and selection pressure (Slatkin, 1987). A number of studies have been reported in the literature that demonstrate genetic variation between and within populations in outbreeding and self-pollinating plants (Woodward and Morley, 1974; Cocks et al., 1976; Price and Jain, 1981; Brown and Burdon, 1983; Schemske and Lande, 1985; Barrett and Shore, 1990; Warwick, 1990b; Bennett, 1997; Bennett, 1999; Cocks, 1999; Dunbabin, 2001; Nichols and Cocks, 2006). The breeding systems of colonizing species are known to play an important role in their success. It is well recognized for example, that among colonizing species, inbreeding is by far the more common system (Henslow, 1879; Price and Jain, 1981; Barrett and Richardson, 1986). However, Cocks (1999) states that many out breeders also make successful colonizers, and that the genetic changes by which this is achieved are less clear. The best example in Australia is annual ryegrass (Lolium rigidum Gaud.), a widespread weed in the cereal belt of southern Australia. Not only has it colonized many different habitats but it also adapts rapidly to changing circumstances. For example, it has developed resistance to some 20 herbicides and can do so within a few years of the first application of spray (Gill, 1995; Owen and Powles, 2010). Similarly, in Canada, wild mustard has developed resistance to several herbicides, including dicamba and MCPA (Webb and Hall, 1995). Other outcrossing weeds that have successfully colonized large areas of southern Australia are salvation jane (Echium plantagineum) (Brown and Burdon, 1983) and cape weed (Arctotheca calendula) (Dunbabin and Cocks, 1999; Dunbabin, 2001). 
In Australia wild radish has been a troublesome weed since its accidental introduction during the latter part of the last century. It was probably introduced into Australia as a contaminant of agricultural produce (Donaldson, 1986), and since that time has successfully colonized a wide range of environments. It is an obligate out-breeder, which can respond rapidly to environmental changes.

Despite its success however, little is known about genotypic variation in wild radish. This study was conducted to determine the genotypic variation between and within populations of wild radish along environmental gradients and to identify the traits that have contributed to the success of wild radish in Western Australia.

\section{Materials and Methods}

\section{Seed Collection}

Seeds of wild radish were collected from 55 sites from road sides across the wheat-belt of Western Australia from $28.7732^{\circ} \mathrm{S}$ to $34.9619^{\circ} \mathrm{S}$, and from $114.6096^{\circ} \mathrm{E}$ to $119.1277^{\circ} \mathrm{E}$. Seed samples were collected every 15 to $20 \mathrm{~km}$ along two environmental transects were a circular route from Perth to Denmark and back via the coast, and then another circular route from Geraldton to Southern Cross and back. (Between December 1999 to February 2000) (Fig. 1). Collection sites represent a range of annual rainfall, temperature and growing season lengths. Each site was about $20 \mathrm{~m}^{2}$ in area sampled by randomly collecting seed from 20 to 30 plants. Vegetation details, habitat type (crop, pasture or roadside) were noted at each site. Latitude and longitude were measured using a Magellan GPS model 315 and recorded as AGD 84 Datum. Climatic data, including average rainfall, evaporation and maximum, mean and minimum monthly temperatures were collected from each site based on data supplied by the Australia Government Bureau of Meteorology (www.bom.gov.au).

The collected material was dried for approximately 48 $\mathrm{h}$ at $60^{\circ} \mathrm{C}$ to remove all moisture. After drying in the oven the samples were further dried in the glass house to ensure that the seeds were dry, but were not damaged by heat, before threshing.

\section{Plant Establishment}

The clean seeds were sown directly into the field on $19^{\text {th }}$ April 2000 field at the University of Western Australia Field Station at Shenton Park, Perth, WA $\left(31.9577^{\circ}\right.$ S, $115.8238^{\circ}$ E) into a Swan Coastal Plain sand. Where possible 10 plants from each site were planted into two blocks, which were arranged in a randomized complete block design. Seeds were sown in rows with $50 \mathrm{~cm}$ between each seed and 150 $\mathrm{cm}$ between rows. Plants were weeded by hand as required and irrigated when required throughout the season. Before planting a basal treatment of super potash at a rate of $350 \mathrm{~kg}$ $\mathrm{ha}^{-1}$ was applied. Later, in early May after the experiment was established the entire area received an application of NPK fertilizer at a rate of $350 \mathrm{~kg} \mathrm{ha}^{-1}$. Glyphosate was applied to the entire planting area prior to sowing to control weeds at a rate of $2.5 \mathrm{~L} \mathrm{ha}^{-1}$.

A number of variables were measured on each plant at time of flowering and at harvest. Details of each of the variables are given in Table 1 .

\section{Statistical Analysis}

Data were analysed using GenStat v.6 (VSN International). Data were checked for normality prior to running a general analysis of variance on each variable to determine variation between and within sites. The sites were then grouped using K-means clustering using standardized environmental variables (variables standardized using Z-scores). Five 'geoclusters' were generated that were significantly different from other, with each cluster consisting of environmentally similar sites (Berger et al., 2004). Mean scores and their standard deviations were calculated for each of the geoclusters.

A principal component analysis was performed on the plant traits with the mean values of each trait at each site used as variates. A correlation matrix was used to standardise the data prior to the analysis, and a biplot was calculated to determine the plant variables that were having the greatest impact on the separation of the sites. The mean PC1 scores in each geo-cluster were plotted against mean PC2 scores, and overlaid with the biplot.

\section{Results}

Wild radish was found to display a large amount of variation for all of the measured traits. Table 2 shows the range of values for each trait over all sites, along with the total population coefficient of variation $(\mathrm{CV})$, which gives an indication of the relative amount of variation exhibited by each trait. The most variable traits were leaf area $(\mathrm{CV}=62 \%)$ and plant height $(\mathrm{CV}=46 \%)$, while the traits displaying the least variation were days to flowering $(\mathrm{CV}=5 \%)$, seed weight $(\mathrm{CV}=19 \%)$ and plant width $(\mathrm{CV}=24 \%)$.

Following analysis of variance all measured variables were found to be significantly different $(P<0.001)$ between sites (Table 2). The proportion of total variation residing between and within sites differed from trait to trait. Seed weight (47\%), flowering time (47\%) and pod weight (39\%) showed the greatest proportion of variation between sites, while traits with a low proportion of variation between sites were number of pod segments $(12 \%)$, not sure proportion of leaf $(9 \%)$ and pod length $(16 \%)$. The proportion of variation occurring within sites is a mirror image of that between sites, and ranges from $90 \%$ (as above leaf proportion) to $51 \%$ (seed weight). 
Table 1: Description of the variables measured on each plant

\begin{tabular}{ll}
\hline Plant trait & Description \\
\hline Flowering time & The number of days from planting until the first flower opened \\
Flower colour & 10 types: 1 , white; 2, yellow; 3, purple, 4, creamy white, 5, yellow with brownish dot, 6, white with purple dot, 7, pink with \\
& white dot, 8, yellow with white dot, 9, pink with yellow dot, 10, brownish with white dot. \\
Number of leaves & At the time when the first flower opened, the total number of leaves on the main stem \\
Plant height & Length of the main stem from ground to shoot apex at harvesting $(\mathrm{mm})$ \\
Plant width & Plant width in north - south and east - west directions $(\mathrm{mm})$ \\
Leaf area & Area of leaf subtending the first flowering branch $\left(\mathrm{cm}^{2}\right)$ \\
Number of branches & The number of branches at harvest \\
Pod length & Mean length of 10 pods per plant $(\mathrm{mm})$ \\
Pod width & Mean width of 10 pods per plant $(\mu \mathrm{m})$ \\
Number of pod segments & Mean of 10 pods per plant \\
Seed weight & 100 seed weight per plant $(\mathrm{g})$ \\
Pod weight & Weight of 10 pods per plant $(\mathrm{g})$ \\
\hline
\end{tabular}

Table 2: The range of values, the coefficient of variation and the percentage variation residing between and within sites for each plant trait; Significance level of the difference between sites (shown in the right hand column) is $\mathrm{P}<0.001$ (***)

\begin{tabular}{llcc}
\hline Plant trait & Range of values & CV $(\%)$ & Variation within sites $(\%)$ \\
\hline Flowering time & 96 to $173($ days $)$ & 4.7 & 55.3 \\
Number of leaves & 1 to $17($ numbers $)$ & 42 & 82.8 \\
Plant height & 3 to $97(\mathrm{~cm})$ & 46 & 79.7 \\
Plant width & 7 to $94(\mathrm{~cm})$ & 24 & 72.5 \\
Leaf ratio & 1.14 to 6.0 & 24.7 & 89.8 \\
Leaf area & 6 to $259\left(\mathrm{~cm}^{2}\right)$ & 62 & 78.9 \\
Number of branches & 1 to $26($ numbers $)$ & 46.9 & 81.5 \\
Pod length & 4 to $90(\mathrm{~mm})$ & $23 * 5^{* * *}$ & 84.3 \\
Pod width & 0.1 to $0.7(\mu \mathrm{m})$ & 30.2 & 55.6 \\
Number of segment & 1 to $12(\mathrm{numbers})$ & 29 & 88.3 \\
Seed weight & 0.26 to $1.61(\mathrm{~g})$ & 19.4 & 51.4 \\
Pod weight & 0.51 to $4.49(\mathrm{~g})$ & 26.9 & $18.4 * 4^{* * *}$ \\
\hline
\end{tabular}

Flower colour was found to be highly variable between sites with all ten different flower colours recorded across the 55 sites. Table 3 shows that the predominant flower colours were yellow, white and creamy white, although approximately $20 \%$ of the Western Australian sites had wild radish plants with flower colours that were across the remaining seven flower colour classes. Almost all plants could be classified as rosettes with upright flowering stems (data not shown).

Pearson's correlation matrix (Table 4) showed that only three plant traits (plant width, number of branches and flowering time) were significantly correlated with any of the environmental and geographic variables; these were annual rainfall and maximum summer temperature. Few other plant traits were significantly correlated with the environmental variables.

Five geo-clusters were found to give the best separation of the sites using K-means clustering, with each geo-cluster containing between 4 and 27 sites. The mean and standard errors for rainfall, mean maximum and minimum January and July temperatures and the range of latitudes and longitudes for each geo-cluster are shown in Table 5. Geo-cluster 1 has no standard error for the climatic variables because each of the sites used the same meteorological station for its nearest observation. Distribution of the geo-clusters are shown in Fig. 1.
Table 3: The number of individual plants from the 55 populations in each flower colour class

\begin{tabular}{ll}
\hline Flower colour & Number of plants \\
\hline White & $371(33 \%)$ \\
Yellow & $385(35 \%)$ \\
Purple & $61(5 \%)$ \\
Creamy white & $140(13 \%)$ \\
Yellow with brownish dot & $42(4 \%)$ \\
White with purple dot & $44(4 \%)$ \\
Pink with white dot & $42(4 \%)$ \\
Yellow with white dot & $24(2 \%)$ \\
Pink with yellow dot & $5(<1 \%)$ \\
Brownish with white dot & $1(<1 \%)$ \\
Total & $1115(100 \%)$ \\
\hline
\end{tabular}

The results of the principal component analysis are given in Table 6 and Fig. 2. The first principal component (PC1) accounts for $36 \%$ of all the variation and the second principal component (PC2) for $21 \%$ of the variation (Table 6). The mean values with their standard error of the principal component scores PC1 and PC2 for each of the geo-clusters are plotted in Fig. 2 and overlaid with a biplot showing the direction in which the most important variables, based on their eigen scores, increase in size (Fig. 2). Fig. 2 shows that for geo-clusters 1,4 and 5 (represented by sites having a high annual rainfall and low average temperature), the plants tend to be larger and later flowering than plants from the more arid geo-clusters 2 and 3 
Table 4: Correlations between measured plant traits, environmental and geographic variables; Significance is indicated as follows: $\mathrm{P}<0.001(* * *), \mathrm{P}<0.005(* *), \mathrm{P}<0.05(*)$

\begin{tabular}{|c|c|c|c|c|c|c|c|}
\hline Plant traits & Annual/ rainfall & January max. temp. & July max. temp. & January min. temp. & July min. temp. & Latitude & Longitude \\
\hline Flowering time & $0.442 * * *$ & $-0.447 * * *$ & -0.223 & $-0.416^{* *}$ & 0.023 & $-0.37 * *$ & -0.018 \\
\hline Number of leaves & -0.034 & -0.097 & 0.178 & 0.061 & $0.338 *$ & 0.093 & -0.125 \\
\hline Plant height & -0.007 & -0.087 & 0.248 & 0.07 & $0.427 * * *$ & 0.164 & -0.219 \\
\hline Plant width & $0.524 * * *$ & $-0.589 * * *$ & $-0.312^{*}$ & $-0.537 * * *$ & 0.05 & $-0.49 * * *$ & 0.035 \\
\hline Leaf ratio & 0.153 & -0.214 & -0.113 & -0.128 & 0.093 & -0.149 & 0.129 \\
\hline Leaf area & -0.178 & 0.133 & 0.000 & -0.078 & -0.219 & 0.066 & -0.084 \\
\hline Number of branches & $0.465 * * *$ & $-0.505 * * *$ & $-0.375 * *$ & $-0.539 * * *$ & -0.178 & $-0.502 * * *$ & 0.183 \\
\hline Pod length & -0.074 & 0.009 & -0.134 & -0.025 & -0.097 & -0.039 & 0.075 \\
\hline Pod width & 0.203 & -0.153 & 0.22 & -0.038 & $0.329 *$ & 0.091 & $-0.403 * *$ \\
\hline Number of segment & -0.004 & -0.015 & -0.179 & -0.07 & -0.117 & -0.101 & 0.095 \\
\hline Seed weight & -0.114 & 0.146 & $0.298 *$ & 0.226 & 0.311 & $0.312 *$ & -0.329 \\
\hline Pod weight & 0.145 & -0.151 & -0.052 & -0.16 & 0.028 & -0.08 & -0.166 \\
\hline
\end{tabular}

(represented by sites having a low annual rainfall, and higher average temperature). Flowering time is later than would be expected for the rainfall in geo-cluster 1, although in absolute terms plants from high rainfall areas tend to flower later than those from low rainfall areas (Table 6). Plants in the large geo-cluster 2, representing plants from the central and eastern wheat-belt, appear to be significantly different from plants collected elsewhere in the state. These plants are predominantly early flowering, smaller in stature and less leafy than plants from other sites. The range of flowering times of each of the 55 collection sites (labelled according to the nearest town to where they were collected) is presented in Table 7 .

\section{Discussion}

The formation of genetically distinct populations adapted to different environmental conditions has undoubtedly contributed to the widespread success of this colonizing species. Among other annual colonizing species, the trait most commonly demonstrating an association with the environment is flowering time, with within species early flowering commonly associated with a short growing season (Woodward and Morley, 1974; Ehrman and Cocks, 1996; Cocks, 1999). For example, Woodward and Morley (1974) concluded that variation in flowering time contributed to the success of Trifolium glomeratum in both south-western and south-eastern Australia. Smith et al. (1995) working with the same species, also found that flowering time was associated with length of growing season, but that other traits were largely homogeneous within two described morphs. The control of flowering time in most Mediterranean annuals is similar, in that they respond to vernalization and photoperiod (Woodward and Morley, 1974). One would expect therefore that flowering time would play an important role in the adaptation of wild radish to Western Australia.

The data in Fig. 2 indicate that the story may not be quite so straightforward in wild radish. Although there is a clear relationship between flowering time and rainfall (Table 4), and there are genetically distinct populations in

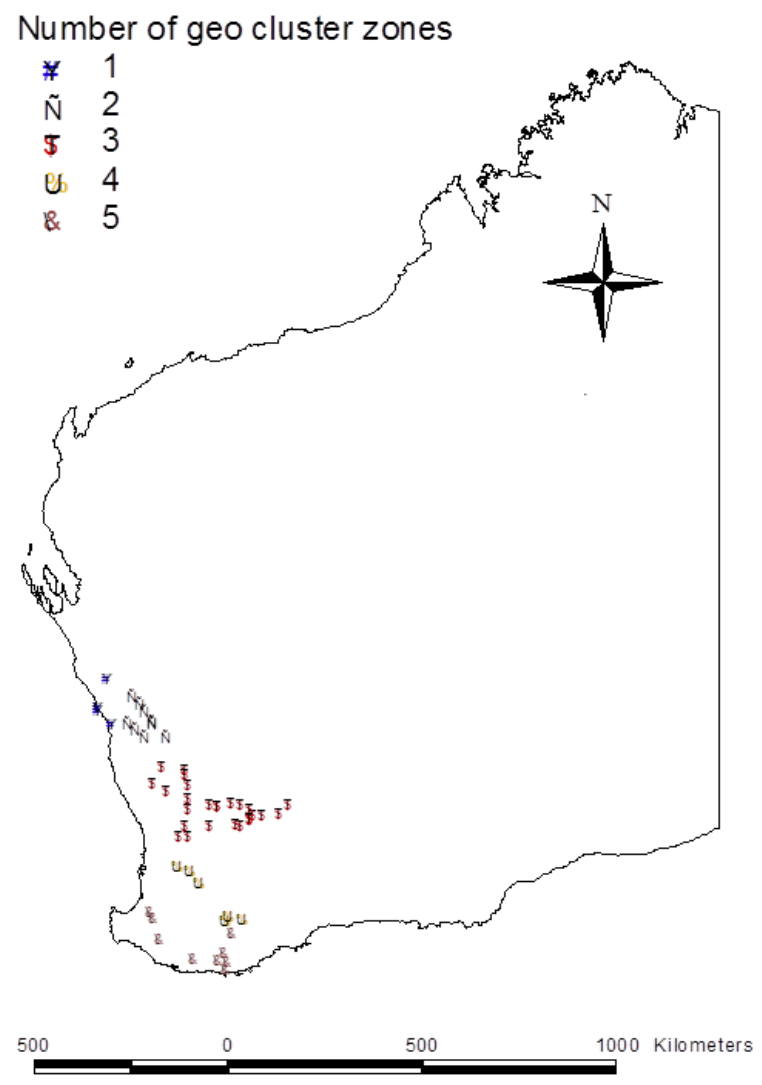

Fig. 1: Map of Western Australia showing the location of the 55 collection sites of wild radish. The legend indicates the localities of the five geo-clusters described in Table 5

regard to flowering time, the data suggest that other factors may be involved. For example, Fig. 2 suggests that geocluster 2, with a mean annual rainfall of $467 \mathrm{~mm}$, flowers later than geo-cluster 5 , with mean annual rainfall of $945 \mathrm{~mm}$. In fact, the mean flowering times of the geoclusters do not differ significantly (Table 5), suggesting that although the relationship shown in Table 4 is significant, the $20 \%$ of variation accounted for by this relationship is not the single reason for the adaptation of the species. 
Table 5: Mean and standard error of the environmental variables for each of the five geoclusters from k-means clustering (see text). Means and standard deviations of flowering time (days after sowing), seed weight (g/100 seeds) and pod weight (g/10 pods). Latitude and longitude are given as ranges

\begin{tabular}{lllll}
\hline Geo-cluster number & 1 & 2 & 3 & 4 \\
\hline Number of sites in cluster & 9 & 27 & 4 & 6 \\
\hline Annual average rainfall (mm) & $467 \pm 0.00$ & $357 \pm 25$ & $376 \pm 55$ & 9 \\
Max. average temp. Jan & $32 \pm 0.00$ & $36 \pm 0.3$ & $34 \pm 0.3$ & $550 \pm 73$ \\
Min. average temp. Jan & $18 \pm 0.00$ & $19 \pm 0.43$ & $17 \pm 0.44$ & $31 \pm 0.8$ \\
Max. average temp. July & $19 \pm 0.00$ & $18 \pm 0.30$ & $16 \pm 0.44$ & $14 \pm 0.11$ \\
Min. average temp. July & $9 \pm 0.00$ & $7 \pm 0.54$ & $6 \pm 0.59$ & $15 \pm 0.16$ \\
Flowering time & $238 \pm 7$ & $238 \pm 7$ & $238 \pm 7$ & $5 \pm 0.66$ \\
Seed weight & $0.76 \pm 0.12$ & $0.76 \pm 0.12$ & $0.76 \pm 0.12$ & $238 \pm 7$ \\
Pod weight & $1.68 \pm 0.34$ & $1.68 \pm 0.34$ & $1.68 \pm 0.34$ & $0.76 \pm 0.12$ \\
Latitude $\mathrm{S}$ & $28^{0} 33$ to $29^{0} 31$ & $30^{0} 02$ to $31^{0} 53$ & $28^{0} 11$ to $29^{0} 15$ & $1.68 \pm 0.34$ \\
Longitude ${ }^{\circ} \mathrm{E}$ & $115^{0} 20$ to $115^{0} 45$ & $116^{0} 0$ to $119^{0} 0$ & $114^{0} 39$ to $114^{0} 39$ & 11.39 \\
\hline
\end{tabular}

Table 6: Component loadings of morphological and phenological traits from the principle component analysis, and the amount of variation accounted for by the first and second principal components

\begin{tabular}{lll}
\hline Plant traits & \multicolumn{2}{c}{ Latent Vectors } \\
\cline { 2 - 3 } & PC1 & PC2 \\
\hline \% Variation & 36 & 21 \\
Flowering time & -0.307 & -0.310 \\
Number of leaves & -0.370 & -0.239 \\
Plant height & -0.333 & -0.387 \\
Plant width & -0.328 & -0.331 \\
Leaf ratio & 0.010 & 0.002 \\
Leaf area & -0.050 & -0.016 \\
Pod length & -0.289 & 0.457 \\
Pod width & -0.374 & 0.085 \\
Number of pod segments & -0.153 & 0.502 \\
Seed weight & -0.375 & 0.154 \\
Pod weight & -0.401 & 0.308 \\
\hline
\end{tabular}

It is suggested that the impact of flowering time is modified by that of seed and pod size. Where pod and seed size are small, as is the case in geo-cluster 3, the time taken from flowering time to maturity is likely to be less.

The relatively early flowering time in this geo-cluster coupled with its small seeds and pods suggests that the species is well adapted to the drier areas of the wheat belt. It is likely that if the seed size been larger, then flowering time would have been even earlier. The plants in geo-cluster 3 are also smaller in stature and therefore have a lower water requirement, whereas plants in most other geo-clusters that are larger in stature have a greater water requirement. Geocluster 1, although early flowering, has large seeds and large leafy plants; geo-cluster 2 has large seeds but smaller and less leafy plants; geo-cluster 4, although similar to geocluster 2 in many respects, produces much longer pods, and geo-cluster 5 which is comprised of plants from collection sites with a higher annual rainfall, is later flowering, and has small seeds but large pods.

The adaptation of wild radish to Western Australia is therefore complex. In this regard, it is similar to colonizing plants in non-Mediterranean environments, where a wide range of life history traits and ecological factors play a role in determining the patterns of genetic variation within and among populations (Barrett and Shore, 1990). For example, the adaptation of $L$. rigidum in mediterranean and nonmediterranean areas is strongly influenced by its resistance to herbicides (Owen and Powles, 2010; Owen et al., 2015), adaptation of Pisum sativum in China is related to environmental factors including abiotic stresses (Li et al., 2013) and variation in Trifolium species across environmental gradients has been linked to days to flowering and other geographic and environmental variables (Collins et al., 2001; Bennett and Galwey, 2002).

The amount of variation recorded between populations was found to be greater than expected for an outbreeding annual weed. Where pollen and seed dispersal are by wind and as a contaminant of agricultural produce respectively. (Allard, 1975; 1988) have proposed that one of the reasons that most colonizers are inbreeding is that inbreeding allows the populations to 'fix' desirable combinations of genes without the risk of their dilution by outcrossing. The results proposed here and by Dunbabin (2001) for capeweed (Arctotheca calendula) and Bennett (Bennett, 2001) for colonising clover (Trifolium) species in Western Australia, suggest that this advantage may be much less than previously supposed. Indeed, the results for wild radish mirror those obtained for capeweed (Dunbabin, 2001), which showed almost as much genetic variation between populations as did Hordeum leporinum, a self-pollinating annual grass. In Dunbabin's (2001) comparison however, the distinction between populations was much less when molecular markers were used instead of life history traits.

There have been a number of studies in southern Australia over the past 25 years investigating genetic variation in colonising species. Most demonstrated that there were few traits that could be linked directly to environmental variables. For example, Smith et al. (1995) found that, of nine life history traits in the inbreeder $T$. glomeratum, just two (flowering time and seed mass) were weakly related to any environmental variable. Similarly, Fortune et al. (1995) noted little variation in flowering time in a host of self-pollinating naturalized legumes in Western Australia and suggested this may be due to introduction of only limited genetic diversity. In eastern 
Table 7: Flowering times (days after sowing) of the 55 populations of wild radish grown in the field at the University of Western Australia field Station at Shenton Park, Perth, WA

\begin{tabular}{|c|c|c|c|c|}
\hline $\begin{array}{l}\text { Name of } \\
\text { Populations }\end{array}$ & $\begin{array}{l}\text { Geo- } \\
\text { cluster \# }\end{array}$ & $\begin{array}{l}\text { First flowering } \\
\text { date }\end{array}$ & $\begin{array}{l}\text { Mean days to } \\
\text { flowering }\end{array}$ & $\begin{array}{l}\text { Flowering } \\
\text { range (days) }\end{array}$ \\
\hline Geraldton 1 & 1 & 120 & 133 & 146 \\
\hline Geraldton 2 & 1 & 106 & 128 & 150 \\
\hline Geraldton 3 & 1 & 98 & 117 & 137 \\
\hline Dongara & 1 & 121 & 135 & 149 \\
\hline Perenjori & 2 & 118 & 122 & 126 \\
\hline Morawa 1 & 2 & 113 & 127 & 141 \\
\hline Morawa 2 & 2 & 100 & 113 & 126 \\
\hline Mullewa 1 & 2 & 95 & 116 & 136 \\
\hline Mullewa 2 & 2 & 102 & 119 & 136 \\
\hline Mullewa 3 & 2 & 105 & 124 & 143 \\
\hline Midlands & 2 & 107 & 121 & 135 \\
\hline Mingenew & 2 & 111 & 133 & 156 \\
\hline Three Springs & 2 & 127 & 136 & 146 \\
\hline York 1 & 3 & 117 & 126 & 136 \\
\hline York 2 & 3 & 99 & 113 & 127 \\
\hline York 3 & 3 & 92 & 109 & 127 \\
\hline Cunderdin 1 & 3 & 110 & 129 & 148 \\
\hline Cunderdin 2 & 3 & 124 & 138 & 152 \\
\hline Tammin & 3 & 106 & 117 & 128 \\
\hline Doodlakine & 3 & 106 & 118 & 130 \\
\hline Noongal & 3 & 102 & 115 & 129 \\
\hline Moorine Rock & 3 & 109 & 122 & 136 \\
\hline Old Nukarni & 3 & 102 & 116 & 130 \\
\hline Nukarni & 3 & 84 & 105 & 127 \\
\hline Nungarin & 3 & 95 & 106 & 117 \\
\hline Trayning & 3 & 117 & 129 & 142 \\
\hline Korrelocking & 3 & 119 & 135 & 151 \\
\hline Wyalkatchem 1 & 3 & 108 & 124 & 140 \\
\hline Wyalkatchem 2 & 3 & 98 & 120 & 141 \\
\hline Dowerin & 3 & 114 & 133 & 151 \\
\hline Wongan Hills 1 & 3 & 121 & 130 & 139 \\
\hline Wongan Hills 2 & 3 & 118 & 132 & 147 \\
\hline Pithara & 3 & 122 & 136 & 151 \\
\hline Carnamah & 3 & 107 & 123 & 139 \\
\hline Moora & 3 & 94 & 114 & 135 \\
\hline New Norcia 1 & 3 & 113 & 131 & 150 \\
\hline New Norcia 2 & 3 & 130 & 141 & 153 \\
\hline Avondale & 3 & 122 & 136 & 150 \\
\hline Merredin 1 & 3 & 107 & 126 & 145 \\
\hline Merredin 2 & 3 & 102 & 122 & 142 \\
\hline North Bannister & 4 & 107 & 121 & 135 \\
\hline Wandering & 4 & 101 & 123 & 146 \\
\hline Williams & 4 & 96 & 116 & 136 \\
\hline Katanning 1 & 4 & 92 & 118 & 145 \\
\hline Katanning 2 & 4 & 114 & 138 & 163 \\
\hline Broomehill & 4 & 89 & 116 & 143 \\
\hline Donnybrook & 5 & 125 & 138 & 151 \\
\hline Ballingup & 5 & 126 & 141 & 157 \\
\hline Bridgetown & 5 & 123 & 136 & 150 \\
\hline Manjimup & 5 & 103 & 126 & 150 \\
\hline Mount Barker 1 & 5 & 117 & 131 & 145 \\
\hline Mount Barker 2 & 5 & 113 & 136 & 158 \\
\hline Denmark 1 & 5 & 135 & 145 & 156 \\
\hline Denmark 2 & 5 & 138 & 150 & 162 \\
\hline Denmark 3 & 5 & 121 & 133 & 145 \\
\hline
\end{tabular}

Australia, Young et al. (1992) detected no genetic variation in populations of the inbreeder, Medicago laciniata and Fedorenko (2000) found very little genetic variation in a number of south-western Australian populations of the inbreeder Medicago minima. Norman et

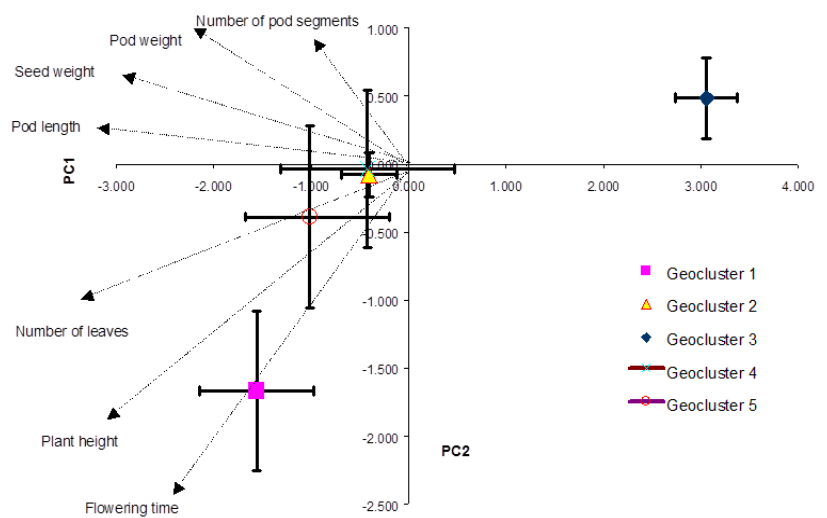

Fig. 2: Principal components analysis showing the location of the collection sites in relation to their plant traits and environment variables. Points represent the mean of PC scores for all sites within each geocluster. Error bars are \pm 1 s.e. An overlay of the biplot indicates the direction in which selected variables increase in value and are not proportional in magnitude to the data in Table 6

al. (1998) and (Bennett and Bullitta, 2003) found that, in a wide array of legumes from Australia and the Mediterranean basin, only flowering time was weakly related to any environmental variable, with no other traits displaying consistent trends. Kon and Blacklow (1988) found that flowering time and panicle emergence of the inbreeder Broumus diandrus were related to growing season length, but that there was no relationship for seeds per panicle, seed mass or seeds per plant. From these studies it can be concluded that many colonisers in southern Australia demonstrate little ability to undergo wide scale ecotypic differentiation.

The above species are predominantly inbreeders. In some cases, outbreeding may have resulted in greater ecotypic differentiation. An example of genetic variation in an outbreeding species has been reported in Echium plantagineum, where 15 traits exhibited significant between site variation, and six were correlated with one or more environmental variables (Wood and Degabriele, 1985). The authors concluded that an ecocline had developed in this species since its introduction. The wild radish populations collected along the two transects in Western Australia have not developed this level of ecotypic differentiation and are more comparable in this respect with inbreeding annuals discussed above.

It is, however, possible that the genetic variation in wild radish is partly the result of multiple introductions of the species (Wools, 1867). The impact of multiple introductions has previously been reported in Hordeum. Cocks et al. (1976) found that of two closely related Hordeum species in the $H$. murinum complex, $H$. glaucum was more successful in the drier areas of South Australia and Victoria, while H. leporinum was more successful in the higher rainfall areas. Indeed, the distribution of the two 
grasses seems discrete, with the $425 \mathrm{~mm}$ rainfall isohyet dividing their habitats. Along this isohyet the species frequently occur together, as they do at Adelaide and Murray Bridge, near where they were likely to have been introduced.

In capeweed, Dunbabin (2001) found a negative correlation between plant size and length of growing season, which he considered to be an adaptation to the more intensive grazing pressure likely to occur in high rainfall areas. In high rainfall areas, such as Denmark and Mount Barker, agricultural land is more frequently used for grazing than in areas with shorter growing seasons, such as Merredin, Geraldton and Mullewa, where cropping is more intensively practiced. There is no suggestion that grazing has had an effect on plant size in this study of wild radish, as plants from geo-clusters 1,4 and 5 (the geo-clusters associated with higher rainfall and therefore increased grazing pressure) are more likely to be larger and leafier than those from the more arid wheat belt area. The explanation is that, even where rainfall is high, wild radish is more likely to be a weed of crops. In high rainfall areas crops are denser and will provide a greater intensity of competition leading to the evolution of larger and leafier weeds. Where cropping is less common, such as in south coastal Denmark, most of the wild radish was collected from roadsides and disturbed native vegetation, neither of which is intensively grazed.

\section{Conclusion}

Wild radish has formed genotypically distinct populations, especially for the reproductive traits of flowering time, seed size and pod mass. While these were broadly related to environmental variables, the relationship was not strong. Genotypic variation should be examined in populations from adjacent sites, where pollen has potential to move between the populations. This would enable the ability of wild radish to form distinct populations where gene flow was not restricted to be mapped. A comparison with other inbreeding and outbreeding weeds would clarify many of these relationships.

\section{Acknowledgements}

The authors would like to thank Dr. Ken Street (ICARDA) and Christopher Loo for their help in collecting the wild radish seed for this project; thanks also to Richard Bennett for critical comments on the manuscript. The authors also thank the School of Plant Biology, Faculty of Natural and Agricultural Sciences, The University of Western Australia, for financial support of the senior author during this study.

\section{References}

Allard, R.W., 1975. The mating system and microevolution. Genetics, 79: $115-126$
Allard, R.W., 1988. Genetic changes associated with the evolution of adaptedness in cultivated plants and their wild progenitors. J. Hered., 79: $225-238$

Barrett, S.C.H. and B.J. Richardson, 1986. Ecology of biological invasions an australian perspective. In: Genetic Attributes of Invading Species, pp: 21-33. Groves, R.H. and J.J. Burdon (eds.). Australian Academy of Science, Canberra, Australia

Barrett, S.C.H. and J.S. Shore, 1990. Isozymes in plant biology. In: Isozyme Variation in Colonizing Plants, pp: 106-126. Soltis, D.E. and P.S. Soltis (eds.). Discorides Press, Oregon, USA

Bennett, S.J., 1997. Genetic variation between and within two populations of Trifolium glomeratum (cluster clover) in western australia. Aust. J. Agric. Res., 48: 969-976

Bennett, S.J., 1999. Ecotypic variation between and within two populations of Trifolium tomentosum (woolly clover) from syria and western australia: Its success as a colonising species. Aust. J. Agric. Res., 50: 1443-1450

Bennett, S.J., 2001. Pollen-ovule Ratios as a Method of Estimating Breeding System in Trifolium Pasture Species. Agronomy Society of Australia

Bennett, S.J. and S. Bullitta, 2003. Ecogeographical analysis of the distribution of six trifolium species in sardinia. Biodiver. Conserv., 12: $1455-1466$

Bennett, S.J. and N.W. Galwey, 2002. The use of spatial analysis to measure the effect of environmental heterogeneity on genetic variation in trifolium species from sardinia. J. Agric. Sci., 139: 283-294

Berger, J.D., N.C. Turner, K.H.M. Siddique, E.J. Knights, R.B. Brinsmead, I. Mock, C. Edmondson and T.N. Khan, 2004. Genotype by environment studies across australia reveal the importance of phenology for chickpea (cicer arietinum 1.) improvement. Aust. J. Agric. Res., 55: 1-14

Brown, A.H.D. and J.J. Burdon, 1983. Multilocus diversity in an outbreeding weed, Echium plantagineum L. Aust. J. Biol. Sci., 36: 503-509

Cocks, P.S., 1999. Reproductive strategies and genetic structure of wild and naturalized legume populations. In: Genetic Resources of Mediterranean Pasture and Forage Legumes, pp: 20-31. Bennett, S.J. and P.S. Cocks (eds.). Kluwer Academic Publishers, Dordrecht, Netherlands

Cocks, P.S., K.G. Boyce and P.M. Kloot, 1976. The hordeum murinum complex in australia. Aust. J. Bot., 24: 651-662

Collins, R.P., A. Helgadottir, M. Fothergill and I. Rhodes, 2001. Variation amongst survivor populations of two white clover cultivars collected from sites across europe: Morphological and reproductive traits. Ann Bot., 88: 761-770

Dunbabin, M.T., 2001. Genetic Variation in the Outbreeding Coloniser Capeweed in South-Western Australia, pp: 51-62. University of Western Australia, Perth, Australia

Dunbabin, M.T. and P.S. Cocks, 1999. Ecotypic variation for seed dormancy contributes to the success of capeweed (arctotheca calendula) in western australia. Aust. J. Agric. Res., 50: 1451-1458

Donaldson, T.W., 1986. Wild radish (Raphanus raphanistrum L.): a review of research on biology and control in Victoria 1976-1982. Plant Protec. Quart., 1: 160-162

Ehrman, T. and P.S. Cocks, 1996. Reproductive patterns in annual legume species on an aridity gradient. Vegetatio, 122: 47-59

Fedorenko, F.D.E., 2000. Ecology and genetic variation of medicago minima (1.) bart. Ph.D. thesis, the university of western australia. The University of Western Australia

Fortune, J.A., P.S. Cocks, C.K. Macfarlane and F.P. Smith, 1995. Distribution and abundance of annual legume seeds in the wheatbelt of western australia. Aust. J. Exp. Agric., 35: 189-197

Gill, G., 1995. Development of herbicide resistance in annual ryegrass populations (Lolium rigidum Gaud.) in the cropping belt of western australia. Aust. J. Exp. Agric., 35: 67-72

Henslow, 1879. On the self-fertilization of plants. Trans. Linn. Soc. Ser. II Bot., 1: 317-398

Kon, K.F. and W.M. Blacklow, 1988. Identification distribution and population variability of great brome bromus diandrus roth and rigid brome bromus rigidus roth. Aust. J. Agric. Res., 39: 1039-1050 
Li, L., R.J. Redden, J. Xuxiao, J.D. Berger and S.J. Bennett, 2013. Ecogeographic analysis of pea collection sites from china to determine potential sites with abiotic stresses. Genet. Resour. Crop Evolut., 60: 1801-1815

Nichols, P.G.H. and P.S. Cocks, 2006. Use of bulk hybrid populations to select for adaptation to contrasting environments in subterranean clover. In: Breeding for success: Diversity on Action. Proceedings of the 13th Australasian Plant Breeding Conference, pp: 330-338. Mercer, C.F. (ed.). Christchurch, New Zealand

Norman, H.C., P.S. Cocks, F.P. Smith and B.J. Nutt, 1998. Reproductive strategies in mediterranean annual clovers: Germination and hardseededness. Aust. J. Agric. Res., 49: 973-982

Owen, M.J., D.E. Goggin and S.B. Powles, 2015. Intensive cropping systems select for greater seed dormancy and increased herbicide resistance levels in lolium rigidum (annual ryegrass). Pest Manage. Sci. 71: 966-971

Owen, M.J. and S.B. Powles, 2010. Glyphosate-resistant rigid ryegrass (lolium rigidum) populations in the western australian grain belt. Weed Technol., 24: $44-49$

Price, S.C. and S.K. Jain, 1981. Are inbreeders better colonizers. Oecologia, 49: $283-286$

Schemske, D.W. and R. Lande, 1985. The evolution of self-fertilisation and inbreeding depression in plants. Empirical Observ. Evol., 39: 41-52

Slatkin, M., 1987. Gene flow and the geographic structure of natural populations. Science, 236: 787-792
Smith, F.P., P.S. Cocks and M.A. Ewing, 1995. Variation in the morphology and flowering time of cluster clover (Trifolium glomeratum L.) and its relationship to distribution in southern australia. Aust. J. Agric. Res., 46: 1027-1038

Warwick, S.I., 1990b. Allozyme and life history variation in five north wardly colonizing north american weed species. Plant Syst. Evol., 16: $41-54$

Webb, S.R. and J.C. Hall, 1995. Auxinic herbicide resistant and susceptible wild mustard (Sinapis arvensis L.) biotypes: Effect of auxinic herbicides on seedling growth and auxin binding activity. Pest Biochem. Physiol., 52: 137-148

Wood, H. and R. Degabriele, 1985. Genetic variation and phenotypic plasticity in populations of patterson's curse (Echium plantagineum L.) in south-eastern australia. Aust. J. Bot., 33: 677-685

Woodward, R.G. and F.H.W. Morley, 1974. Variation in australian and european collections of Trifolium glomeratum L. And the provisional distribution of the species in southern australia. Aust. J. Agric. Res., 25: $73-88$

Wools, W., 1867. Plants Introduced Accidentally (1866), pp: 136-152. In: A contribution to the flora of Australia. Sydney, Australia

Young, R.R., P.H. Croft and G.A. Sandral, 1992. Variation in flowering times and agronomic characteristics of medicage laciniata (1.) miller collected from diverse locations in new south wales. Aust. J. Exp. Agric., 32: 59-63

(Received 14 December 2015; Accepted 13 June 2016 